\title{
Perspective
}

An occasional series in which contributors reflect on their careers and interests in psychiatry

\section{Forensic Psychiatry in the UK}

\section{A contribution from Patrick McGrath}

'He that sinneth before his Maker, let him fall into the hands of the Physicians'.

ECCLESIASTICUS, XXXVIII, 15

Here surely is the scriptural authority for the existence of forensic psychiatry, even though one interpretation of the text could be that medical care is a fate literally worse than death. In fact, however, forensic psychiatry grew up largely from the efforts of lawyers to use medical expertise to save their clients from the execution of a death sentence, and their efforts antedate the historic trial of Hadfield by many years, indeed centuries.

In those earlier times, before the eighteenth century, the diagnosis of madness was made by the court on evidence of strange behaviour, given by friends and relatives. It was not until 1760 that a doctor, the legendary Dr John Monro of Bethlem, was specifically engaged by the defence to report on the mental state of the accused, Lord Ferrers, who had shot his factor. The precedent was an unhappy one, however, because the noble Lord was found guilty by his peers, and promptly hanged. Other, less calamitous, results followed medical intervention in the succeeding decades, but it was not until Hadfield's case in 1800 that Parliament addressed itself to giving statutory authority for the appropriate disposal of the mentally disordered offender. The trial judge had ordered that the brain-damaged, depressed, and deluded veteran of the Continental wars should be cared for, 'all mercy and humanity being shown'. The jury duly found him 'Not Guilty by reason of Insanity', and Hadfield's committal to Bethlem was retroactively legitimized by the Act of 1800 'for the safe custody of insane persons charged with offences'. (In the debate in the House of Commons the Attorney General sounded a note all too familiar to our ears, when he complained of the premature discharge from asylums of insane persons, and wanted something to be done about it.)

It is worthy of note that just a few years later, in 1812, Bellingham, just as manifestly psychotic as Hadfield, shot dead the Prime Minister, Spencer Percival, and was tried, sentenced and executed all within a matter of days.

McNaughten's case, in 1843, is often held to be the 'fons et origo' of forensic psychiatry, and indeed the eponymous Rules still crop up, even though lawyers and doctors keep on saying 'nous avons changé tout cela'. Briefly, McNaughten, a paranoid schizophrenic showing most of the first-rank phenomena of his illness, shot and killed Drummond, secretary to Robert Peel, the Prime Minister, who was the intended victim. He was acquitted on grounds of insanity, which verdict provoked a public and Parliamentary outcry and a demand, led by The Times newspaper, that the law on insanity in relation to crime should be clarified. The whole Bench of judges, fifteen of them, were invited to expound the law to the House of Lords, and to answer five specific questions put to them, three of which were essentially technical jurisprudential ones. The meat of the answers, as far as doctors are concerned, lies in the passage: '...to establish a defence on the ground of insanity, it must be clearly proved that, at the time of committing the act, the party accused was labouring under such a defect of reason, by disease of the mind, as not to know the nature and quality of the act he was doing; or, if he did know it, that he did not know that he was doing what was wrong'.

These Rules, in the course of the succeeding hundred and forty years, have been the subject of study and exegis of a complexity which would rouse the admiration of medieval schoolmen or Talmudic savants.

Perhaps surprisingly, the judges' report did not bear fruit in legislation, and an Act specifically directed to the Criminal Lunatic did not reach the Statute Book until 1883-4, and then only at the insistence of a highly indignant and totally unamused Queen Victoria, who objected to her would-be assassin, MacLean, being 'acquitted' on grounds of insanity. The Queen's phrase 'Guilty but Insane' was replaced by the original 'Not Guilty by reason of Insanity' by the Criminal Procedure (Insanity) Act of 1964.

A special facility, in the shape of Broadmoor Criminal Lunatic Asylum, was established in 1863 to care for the Criminal Lunatic and insane prisoners, and perhaps, could be said to have given forensic psychiatry 'a local habitation, and a name'. It was entirely appropriate that one hundred years later the Forensic Psychiatry Sub-Committee of the Royal Medico-Psychological Association should have been formed at a meeting in Broadmoor Hospital. The first Medical Superintendent would, I suppose, have been entitled to call himself a Forensic Psychiatrist had it occurred to him to invent the phrase.

Medico-legal bonds were further strengthened by the first of the Mental Deficiency Acts, in 1913, which addressed itself to the relationship between 'mental deficiency' and offending behaviour by authorizing a medical disposal, to an 
appropriate institution, of mental defectives who had been convicted of offences. A little later, in 1922, the Infanticide Act said that a woman need not be found guilty of murder if she took the life of her newly-born child while the balance of her mind was disturbed' (and by 1965 all of these unhappy women were being given a medical disposal).

Parliament helped to consolidate the position of forensic psychiatry by some of the provisions of the Criminal Justice Act of 1948 which legislated for what has come to be called a psychiatric probation order, i.e. a probation order incorporating a condition of psychiatric treatment, either as an in-patient or an out-patient. Again, in 1957, the Homicide Act introduced into English law the concept of 'diminished responsibility' manslaughter in murder cases, a concept which is rapidly building up a body of disputatious literature as large as its ancestors the Hadfield Act and the McNaughten Rules generated, and as much court-room dialectic.

In 1959 Holy Writ, in legislative terms, of forensic psychiatry was promulgated in the shape of the 1959 Mental Health Act. An attempt was made to define a category of patients, those suffering from psychopathic disorder, whom many believe to form the bulk of the case load of forensic psychiatrists and the institutions they serve.

The Special Hospitals, where the problems are seen in their most extreme form, had their role defined, and their place in the mental health services of the country identified. Perhaps the most important feature of the Act is that it departs from previous legislative provisions for the Mentally Abnormal Offender in that it does not demand a casual relationship between offence and mental state to qualify for admission to a Special Hospital; the subject must simply be of 'dangerous, violent or criminal propensities', not necessarily a person who has been convicted of criminal behaviour directly arising from mental disorder.

Parallel with changes in parliamentary and public attitute, as reflected in changes in legislation, the profession of medicine has become more aware of the special needs of the Mentally Abnormal Offender, and doctors have written about the clinical dimensions of their identification and care. Perhaps the first major work was that of Dr Haslam in 1817 who wrote of 'Medical Jurisprudence and Insanity'. In the middle decades of the nineteenth century, Isaac Ray (in America) and Prichard in this country wrote texts which are still quoted. By the 1920 s, forensic psychiatry was a recognized discipline, with a lectureship at the Maudsley occupied by Dr Norwood East, who wrote a book called simply Forensic Psychiatry in 1927. It is almost exclusively devoted to amentia and to discursion of the criminal responsibility of aments. In due course the lectureship became a readership, and the Reader, Dr Trevor Gibbens, was eventually awarded a personal professorship; now there is a definitive Chair of Forensic Psychiatry at the Institute.

The specialty was favoured, and its growth stimulated by the great personal interest of the late Sir Denis Hill, and was adorned by Dr Peter Scott, Consultant in Forensic Psychiatry at the Maudsley from the end of World War II until his death.

Since 1956 my own view of forensic psychiatry has necessarily been through Broadmoor eyes. When I was first appointed Medical Superintendent, the hospital was run by the Board of Control, of not entirely unlamented memory. The Board had taken over management of the hospital from the Home Office in 1949, and Home Office attitudes and practices still dominated the scene. All patients, without exception, had come from the Courts directly or via a prison sentence, and their fate lay in the hands of the Home Secretary. His officials recognized only the Medical Superintendent, and there were no such things as Responsible Medical Officers. My reports on patients initially were on a century old scale. 'Insane' (tout court) proceeded to 'Unsound' and on to 'Rational' and finally 'Rational and Tranquil'. This phrase had the magic properties of 'Open Sesame' and the Home Office was then prepared to consider discharge to the care of a 'guarantor', usually a close relative. Transfer to conventional, Regional Hospital Board hospitals (known to patients and officials as 'the counties') was only permitted if the patient met certain criteria-he must be floridly, 'certifiably' insane, of such poor prognosis that 'the County' would be extremely unlikely to discharge him, and he must be harmless. In effect, therefore, it was only patients well advanced into dementia who became subject to "conversion (to NHS as opposed to criminal status) and transfer'-a mere handful each year. When necessary, a magistrate and a local GP came along, a 'certificate' was written and the patient compulsorily transferred to his local hospital, which did not have the power to refuse him admission (O happy days!).

A small minority of nursing staff were $\mathrm{RMN}$-but they were all mature and loyal men and women, knew their patients well, and protected them much as many of them had protected their recruits when they were regular MCOs. The Board of Control had a robust attitude to luxuries such as teaching and research-simply, it was not our job to pursue such activities, and anyway there was only myself and one other consultant, no department of clinical psychology and no social workers.

The 1959 Act came in like a tidal wave. It swept away the Board of Control, whose members, however, promptly reappeared as a Management Committee, but with radically changed attitudes, and they were of inestimable support and help in the ensuing years. I happily swam along with the tide of advance and reform, and welcomed, in 1959, our first clinical psychologist (who now heads a staff of ten) and our first professional social worker. I watered the growing plant of consultant establishment to its present luxurious stature of ten whole-time equivalents, of whom four are half-time psychotherapists. Nursing staff developed its professionalism, and achieved for the hospital GNC recognition as a school of psychiatric nursing. Far from research being 
eschewed, the hospital sired (or at least was godfather to) a Special Hospital Research Unit.

In the big outside world, 'forensic psychiatry' became a familiar and acceptable description of a subdiscipline; flourishing academic departments came into being in Edinburgh and Birmingham, as well as at Denmark Hill. Reports and publications proliferated, and Regions were encouraged to set up special units and appoint consultants to cater for forensic psychiatric needs. Now a sister Special Hospital has taken root and flourishes on Merseyside.

The essentials of the job at Broadmoor, however, have not changed, though in the performance of it one increasingly had the support and advice of colleagues of many disciplines. These essentials were and are the treatment and assessment of those who have been statutorily labelled as 'dangerous', the protection of the public, and the protection of the rights (including the right to treatment) of patients. The work is carried out in the increasingly lurid, sometimes blinding, glare of publicity; one must react, and not over-react, to public interest and public pressures. Some twenty years ago, an official asked me if I did not feel isolated; I had to reply that I felt as isolated as one standing in the middle of Piccadilly Circus, which my office sometimes resembled. To my great enjoyment, visitors come to the Hospital in single spies and in battalions; from California, from Cathay (literally!), and nearly everywhere in between-politicians and professors, dons and do-gooders, the critical and the constructive. Many came to preach-but some, with enough humility, came to learn. Above all, there were the patients, all the time; many with tragic histories, some tragi-comic or bordering on the farcical, and some were deeply moving. It was they and their relatives who made it all worthwhile. Despite the pressures, public and political, one was never moved to apply for 'conversion and transfer'. When things were going well, there were no greater rewards or fun to be had in psychiatry; when things were going ill, one could not possibly quit.

So I lived out a quarter of a century as the last Medical Superintendent of Broadmoor, and have now, rational and tranquil, handed over to a Medical Director.

ACKNOWLEDGEMENT

Much of the historical paragraphs relating to development before 1900 is based on Professor Nigel Walker's Crime and Insanity in England, and I am indebted to him.

\title{
Clinical Hypnosis for Psychiatrists in Training
}

\author{
W. A. Barker, Lecturer and M. Place, Senior Registrar, Department of Psychiatry, Newcastle upon Tyne
}

Interest in the application of hypnosis to clinical psychiatry has increased recently in this country. In the 1950s it had been recommended (Subcommittee of the Psychological Medicine Group, 1955) that experience of the techniques of hypnosis should be available to all medical undergraduates and to postgraduate trainees in certain specialties, including psychiatry. Such a training would lead to an awareness of the practical use and limitations of hypnosis, and would also allow an informed and rational decision to be made about its employment in the practice of medicine. Despite this recommendation, a review twenty years later (Scott, 1978) showed that teaching of hypnosis was a rare feature of medical training.

Most of the teaching about hypnosis and its techniques is carried out on courses organized by the British Society of Medical and Dental Hypnosis, and the recently formed British Society of Experimental and Clinical Hypnosis. The techniques taught are varied and are applicable to many areas of medicine and dentistry, but it may be prudent to ask whether these courses meet the specific needs of psychiatrists in training. In Newcastle four courses were organized in the Department of Psychiatry which were quite separate from those run by the national societies. Teaching was done by psychiatrists who use hypnosis regularly as part of their clinical practice, and the courses were open to all psychiatric trainees in the area. The impetus for establishing the workshop was from trainees who, knowing of the interest in hypnosis of some local psychiatrists, sought out instruction in its techniques.

The course is designed to focus on factors that seem of particular relevance to psychiatric work. It is assumed that trainees are attending the course to gain knowledge and are not necessarily planning to use the techniques clinically. Emphasis is laid upon the fact that hypnosis in psychiatry is not an all-embracing treatment, but more an additional therapy to be used as and when appropriate alongside established treatments. The sessions are primarily experiential because this helps towards a clearer understanding of the phenomena of hypnosis and highlights the facets of the process that may be of potential therapeutic benefit. The whole programme takes approximately six hours, but each group dictates the actual intensity and depth of the course. The format is flexible and tailored to accommodate the work circumstances of the participants. A manual is distributed beforehand containing descriptions of induction procedures and treatment strategies which are to be illustrated.

\section{Course structure}

The programme can be divided into five parts. The first segment consists of an introduction to the subject of 